な応勢示ま云眼たた管著潙

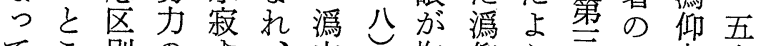

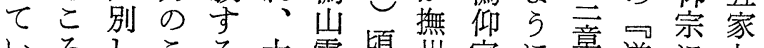

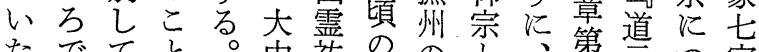
たでてと。中裙ののと第䓕つ宗

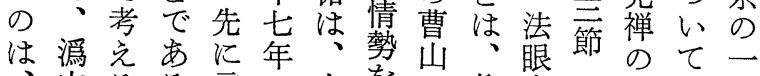

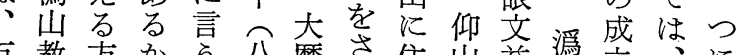
百教方吕5公糜さ住山益派立、に 丈団㤎占仰吾六乙崇会宗史究数 懁の便、山年てたの分宗的朚兄 海動利こ宗正宅同こ公研导ら

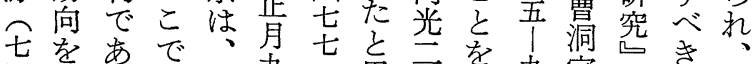

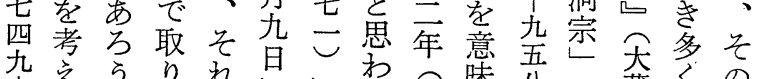

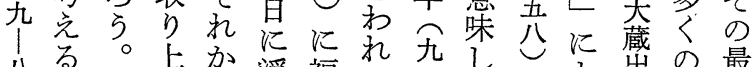

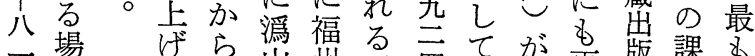

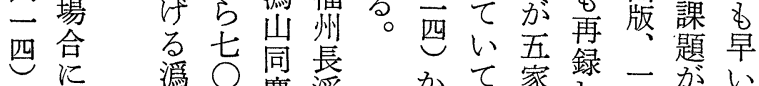

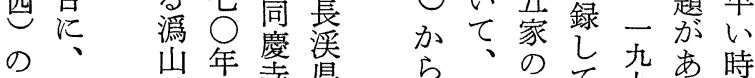
法以教程寺県 ら只て艻市時 嗣前団後での 天炅方明元る。期

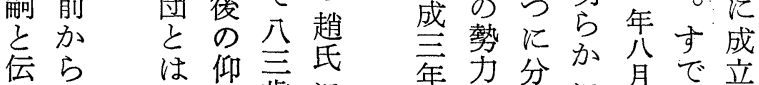
伝気仰歳に年力分に月で立

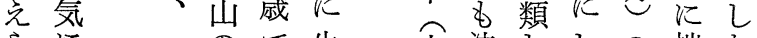
らに一ので生旮法ししの拙た

地こ新年を潙でう大問と大弟れ がに店は訪私山离安題は安子る

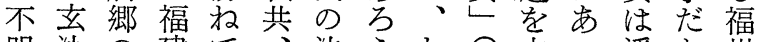

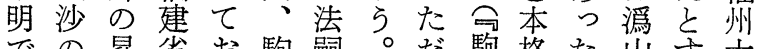
での昇省お駒嗣。だ駒格た山す大 あ募山とり沢飞なこ㳄的がのる安 口が霊広、大数挍の学飞、弟之会 た存镢東既学艺、論学検細子、七 だ在寺省にのて尾文学討加潙旮

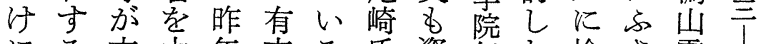
にる玄中年志る氏資年た検さ需八 大こ沙心ではこか料報論討わ祐八

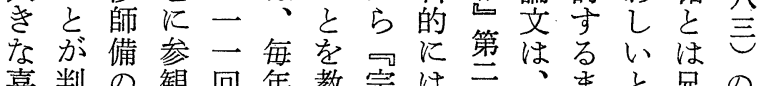
喜判の観回年教宗は言、委々兄の び明塔しをの学留制号尾でい弟存 をし院た数よて統約岳崎にく弟在 味たで。党らい要が二正はつ子で わこあ八てにた集あ九善至か子あ

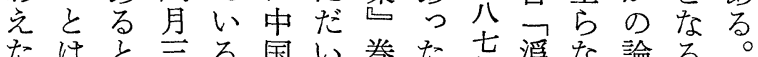

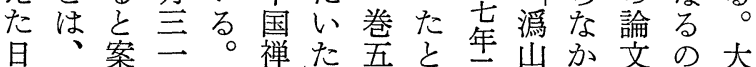
で玄秀日た宗。吾言击霜っでで安

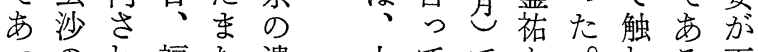
つの机福た遺大てでと。机る百 た遺、州㐬蹟安よ市福こたが文 。蹟そ市昨地をいろ州のこ、の

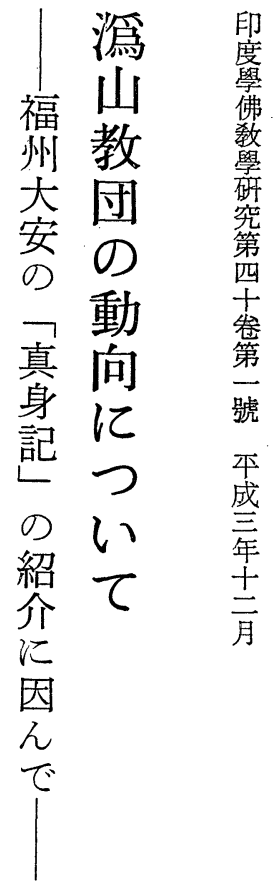

石

井 修

道 


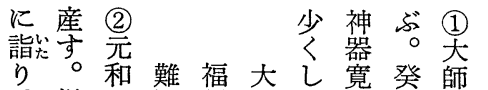

側元 り。和難福大祥蕒癸師

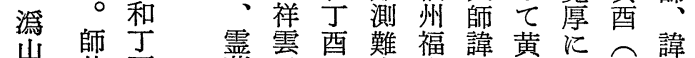

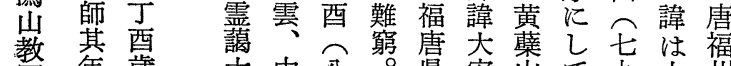

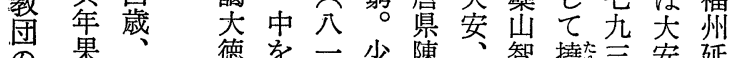

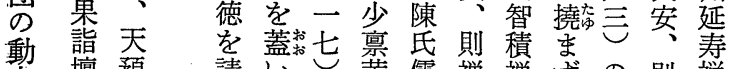

憅壇預請い感黄儒禅禅ずの則禅

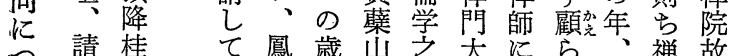

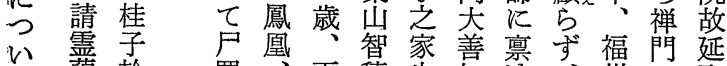

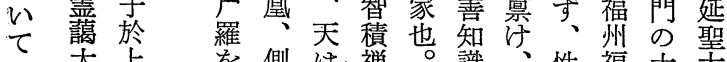

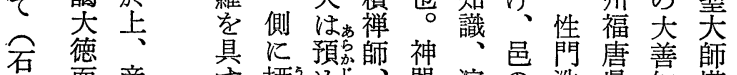

石 德産具拪預㤎師神、邑哭演唐善師

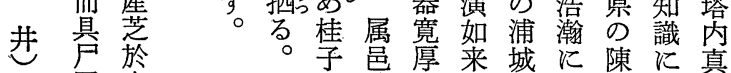

師を浦厚㵊城に陳に真し 上城不上有ての記

祥其を県撓乗の測儒如

雲 のり有不。戒り学莱

蓋年降 戒 顧 癸壇 難の の

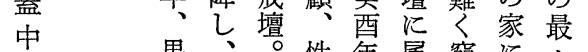

果、酎年属窮海上

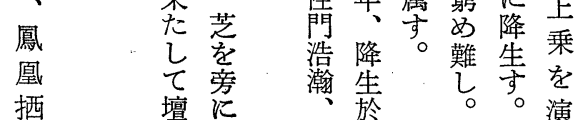

拪

\section{壇 亿}

らをき

雨元て先始和

桂和、。始

子士詔刺て主

及年元元芜年

地、鳳錫を公

生勅棲手全一

草洲寺 5 其卞

剌城め瑞時建

史県需尔浦

元錫莞需踈 天浦

錫元感しは城

手疎寺壇て桂臬

其置号旒品索乾

瑞鼠 寸

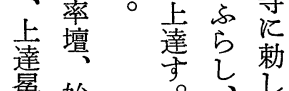

竟始 す ᄂ 兄

旒全遂及て

遂售垈御地率

御時。礼洙を

礼照迴草置
字盟 真聖れ

二 寺躬全塔々 5 途

二内記知内のに会

行の心ら真石、西

で壁碑れ身碑最郊

書に障る記は近に

から荟こし、近

れめでと欠驚井る

、込碑の卡く户怡

合ま碑な 陽なか山

計楊い真さら西

六てば福躬こ発禅

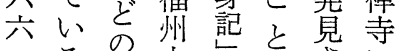

二る。宁よをにされ

字。安略格立

ら基に本碑称唐と寄

ら本な碑守唐とつ

る 字っ でと福いた

も数いあ題延石案

のはつさ寿碑内

で二るなた行禅をを

あ行の。院紹ら

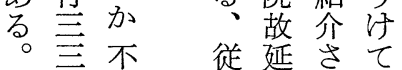

さ段撰た福安き最

らにしに州伝る下

に分に解大 $\leftarrow \circ$ 部

検汗な明安に内宓

討てるさが近容欠

姓洲

陳怡る下真た部㯰がにて

氏出とに身部懷、は、

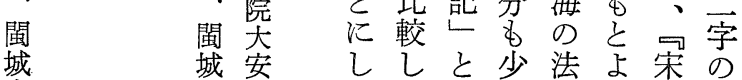

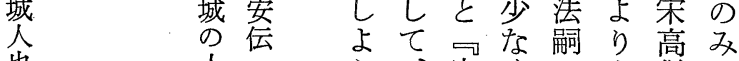

也人 人宋くで全僧不

幼 り案大高なな同伝明

年安僧いいでしで

幼曾㤎伝。こは巻あ

年 伝

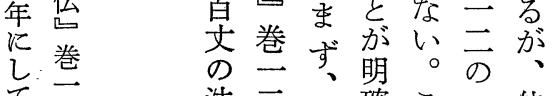

頓

道 $三$

戝

入

り

頓

に

塵
法二马確こ一他

嗣の参との唐の で大学な碑福文

は安比る文州字

な伝丘なに怡は

いを允どよ山解

点三朚 書新、院読 
(6) 次にに (5)

爱气で、上却虽

に国五却京定元に

長台之国中に臨?

沙詢、臨飞の返洛心

の道続洛之所回罧

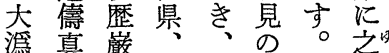

出真繁止道如耆き

に照をし翼

至 如提詢上。㕛招

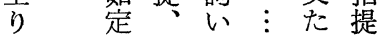

大 中示真䓯引代

円 所入を龍予止

大 見定儔の炎 ま

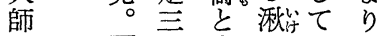

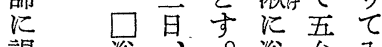

謁浴、。浴台入

寸 毒方守它

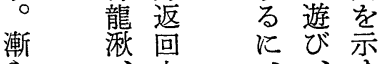

占 卡 元続 导

徒無者鱼市

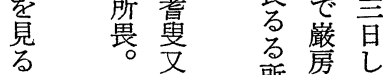

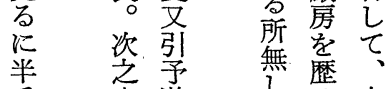

手京遊等方
る て (4)

明夕ば (3)

師 便

曰 入

無 撫

菩 石。

提 山

有 礼

人, 蔵

戴 禅

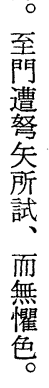

禅

か試便虚便

ら撫字遊ならう上

る州。上の行完䳕

る石名元、禅せ

䂬聞、繁長ざ遊

懼山 歪中紊老る壮

るに禅路はのとん

る入長逢徒云勧と

色り老一守らめす向

無、宾叟にをるらるる

乙 恵

禅 禅

師 師

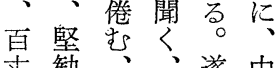

光礼

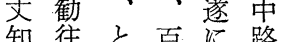

く礼、昌師はに一

ᄀ 定虔㮌知従叟

宝虚頓識いに

無門: 自行にに、逢

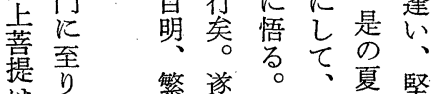

其 努

人矢

に遭

有 以

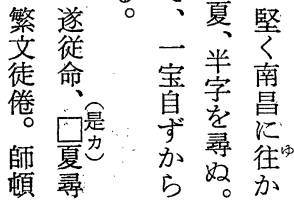

山
教
の
動
向
に

v

石

後

b

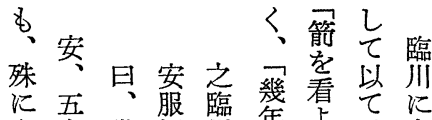

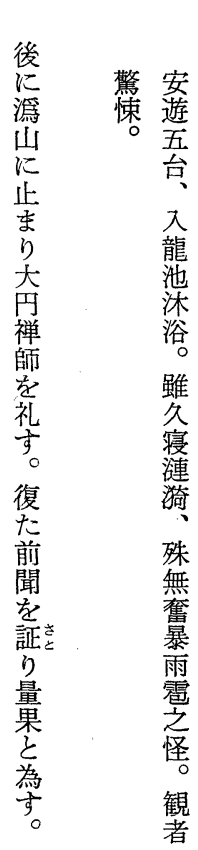

る参に

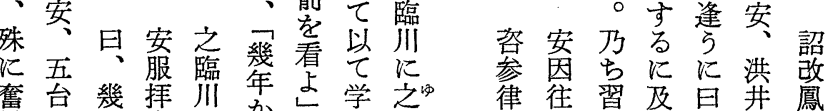

奮台幾拝川出学市律往署及日羊鳳

霜遊射興見射安を括

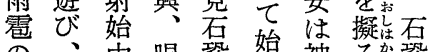

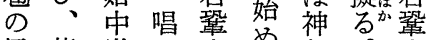

怪龍半日昌め色。草

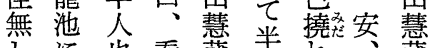

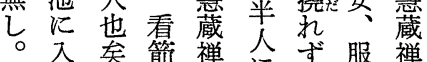

観り答拝師

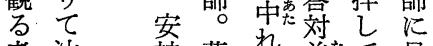

者沐神蔵督差势見

驚 浴

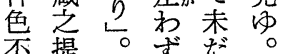

慎

殊
無
䍜
暴
霬
怪
観
者

久 撓唱舆蔵

乙答必留る提

人詨持草淐

漣器势

渏哀差

寝石以

る 䇎擬

と $\begin{aligned} & \text { 乃 } \\ & \text { 雖 } \\ & \text { 学 }\end{aligned}$

䋈唱次

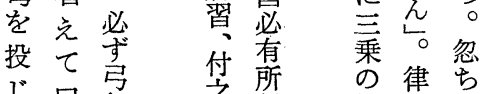

学洪宑所でく往等

夜、学夜

聞路 夜子允号

僵出出三 南寺

㠊忽人談乼

遽逢付論价り

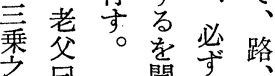

㫐白留得

乃往遂留 有

南南出

じ㛎 垈得 旨学

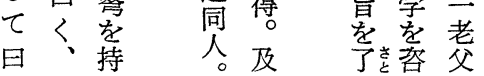


9 如事を府 (10)

(9)

$\tau$ 寺 (8)

艺。有元西楅

庚

禅㳊末

\begin{tabular}{ll} 
た & 7 \\
$\vdots$ & 乙 \\
\hdashline & 井
\end{tabular}

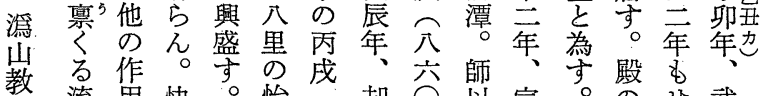

教流用快。怡成

団流用快。怡 却 $\bigcirc$ 以宣

の

動

禁に師山公交の閉宗$$
\text { 得 }
$$

问

て却出毎禅

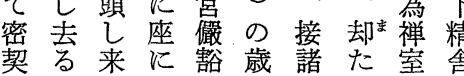

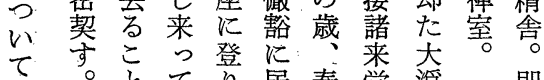

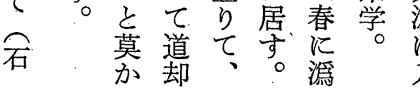

井

机着無嘗 水

せ為气

快を学毛離

に先 り有

活聖七方秋

し 去出く閩福

去世く、の州

势電什乗到

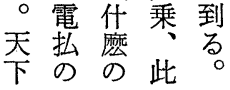

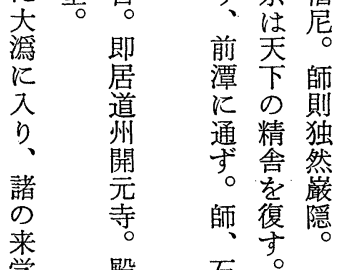

$\begin{array}{lll}\text { 来 } & \text { 学 } & \text { 殿 } \\ \text { を } & \text { 石 } \\ \text { を西 } & \text { 即 }\end{array}$

接有 以占

寸 魅穴導

通閏突開

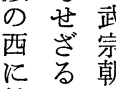

魅 に

劣

り宣澛

丑自稂爰至大专大擁

公詯㦑長露円色師

五露虎大醍く葫

の醐 狼潙

年㗅固山

、可而謁

武堪居大

宗 朝潤 点

僧従 百師。

尼此大漸

沙譚界見

汰 理

○㐫嶊至異 多

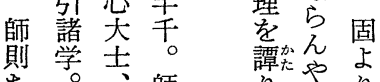

㦑崖師

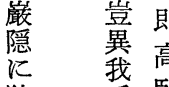

独我高

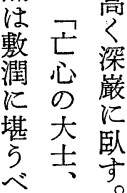

ᄂ

此兄我虎

上犯狼

至異多

り怘 り

諸自注

を謂㝒

引 兄

後
齒
山
礼
大
円
禅
師
復
証
前
聞
而
為
量
果
也
员 
陰と以る柏に師ず (12)

の六を (11)

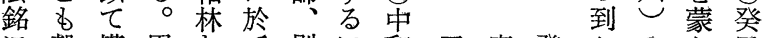

掌是中に穀塔甲たて則に和又度癸りの包去事嘗懿

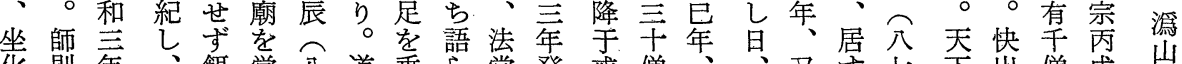

花則年、慨営分道垂堂癸戒僧、守七年出僧成

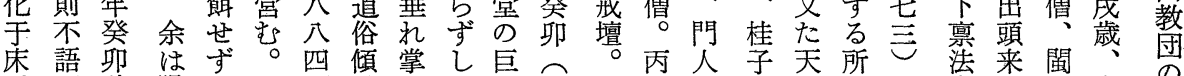

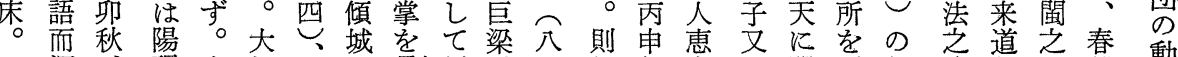

日迴、碣寿師四乙嫣延、公知年真。聞延年流却大離動

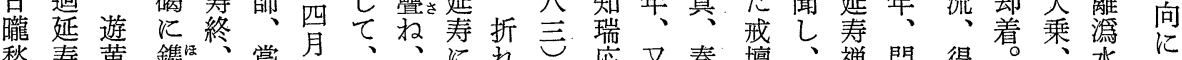

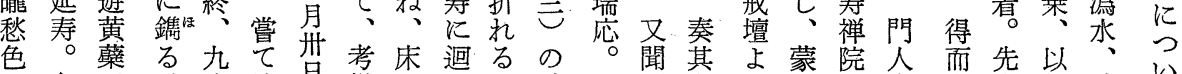

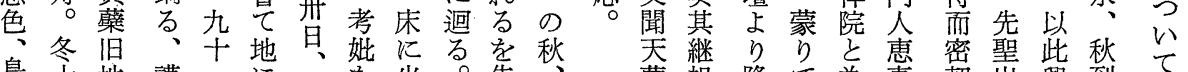

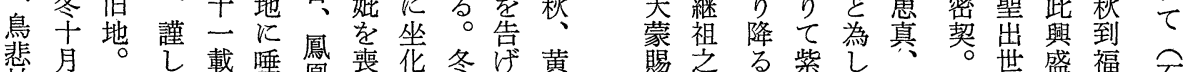

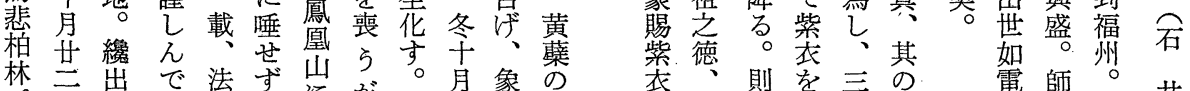

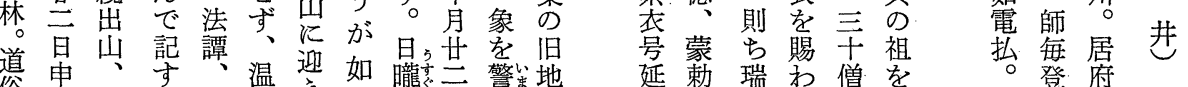

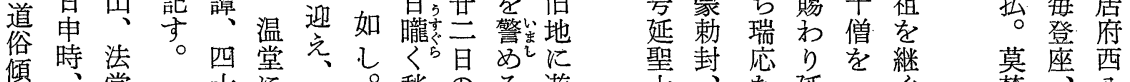

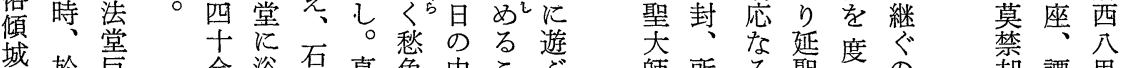
城於昰余浴蔵真色申こ䇼師所る聖度の 却譚里

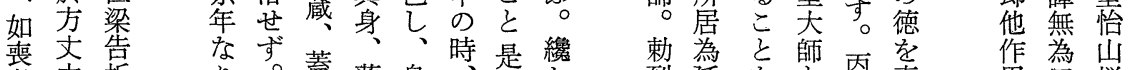

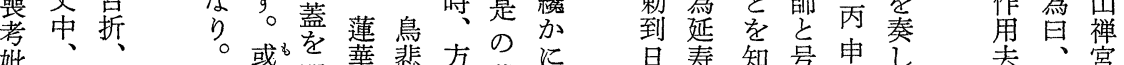

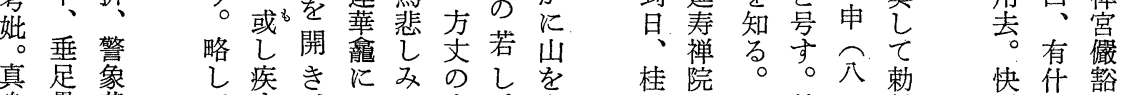

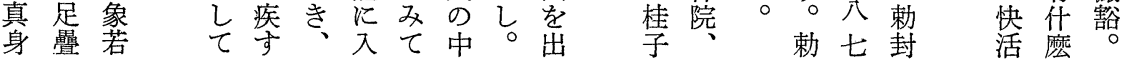

(口) 日 $($ (1)

続 坐 和

詔 化 二

賆 怡年

怡

智 山 示

大疾

師 㗌 所

荅春步

証 九 堂

真十豆

安、采

䪹臘折

唾十三

地 年

不卯

処十

温 月

房 二

随 索

化 二

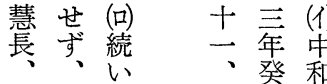

に房詔六へ年梁道予副ない契予

入にし十公㚣廉をり、の

り処七七分副疏使賜。安廉

て 円方公。召㮩感の使

安ず智声主贈る通道

德 化 師

をに

揚 随 贈

ぐいり

故衣塔

に、を

追 湓 雨 真

有灾 と

り号

て

守

諮嘗

法 乙

总地

子唾
十 疾 尉

月疾誉 崔

二省愈貞

三尔昌孝

日感

怡步通則

山乺四公

丈法年季

室堂詔 父

夎渠察延梁

す中 聖 玄

春折師就

九。賜安

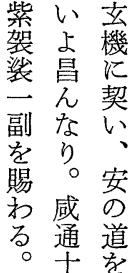

四 敦 太

年 5 尉

分 ᄂ 㑺

七疏孝

三を公

㫣は

詔 睦

宣无

乙之魏

延を公

聖召季

大 季

師厥な

c

号 誉。

しは深 
な知なっああわのこ伝も現撰 くららたるられ司之兄の存口従 撰なら。のがら、空でのでし大来 临述い。で、。苯相、111 ‘潙

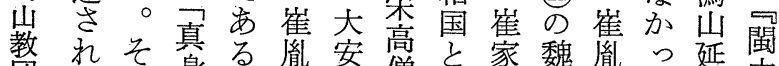
団たれ身るか胤安僧々家魏胤り延中

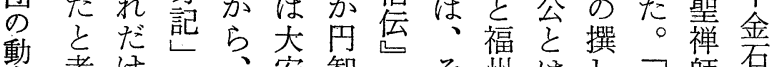

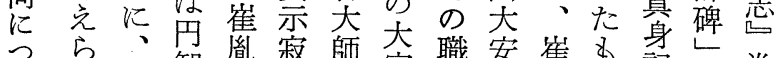

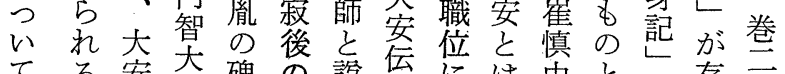
てる安大碑 の湓伝には品之は存队

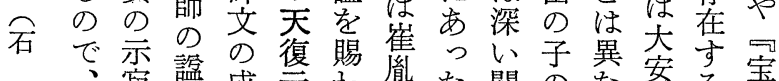

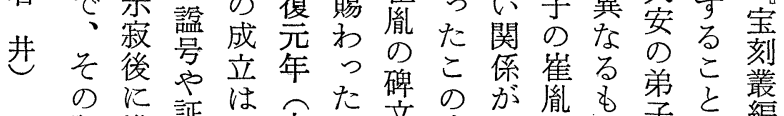

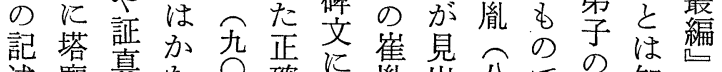

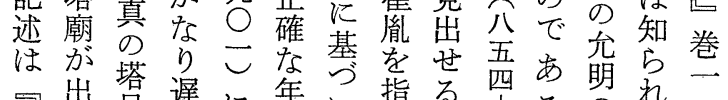
宋出号逗に年い指る 四る の的九

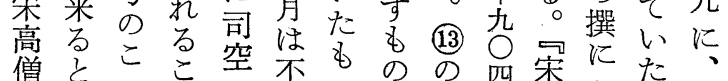

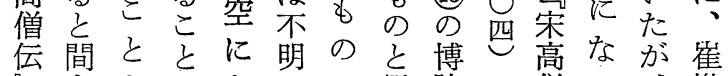
らもをになでで思陵の僧る、凧

のら洪あにの元 む、巻、のよ 石。州る出後寺大、、九大混り 門馬開犬゙会にの安真宋の安乱舟 山祖元ろ心遊悤は真香系の法正 では寺 $5 、$ 行率元記僧統伝、確

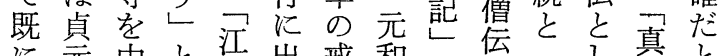

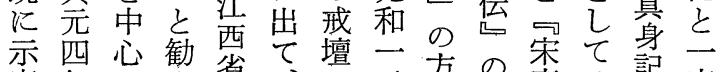

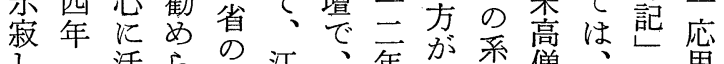
乙も活ら南蘇霍 年正統僧品に思 い八公てた昌省藹八確に属祖よれれ

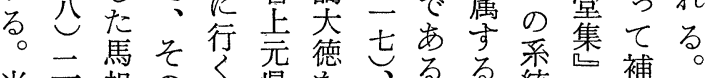

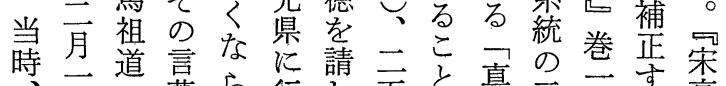

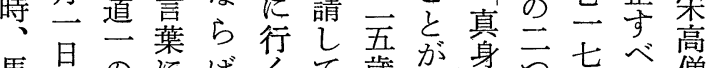

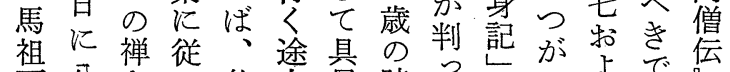
下分指た道で戒に時たが存びあ゙市 代歳㧹た道で戒に建。出在司らの 表での南衍一受州 現し景ら 6

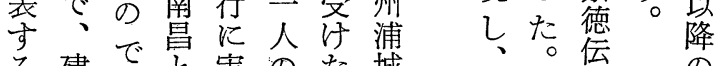
る建で実の城しこ燈記 人負か 


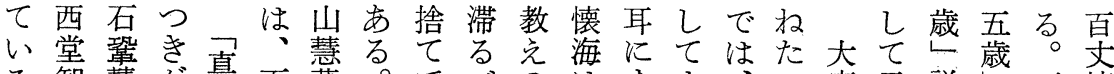

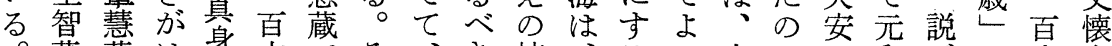
。蔵蔵は躬丈でそ、核、るい小では和㤎の文海

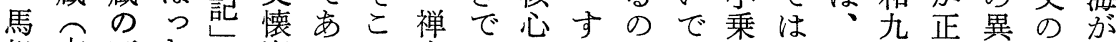
祖七下き海るで宗はをぐであ教な南年し説示い

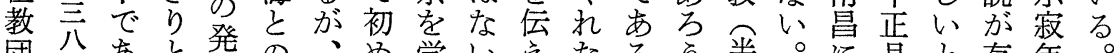

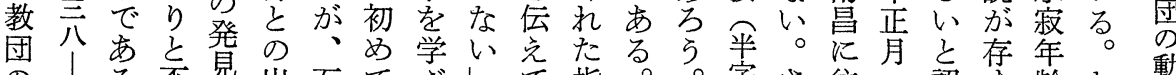

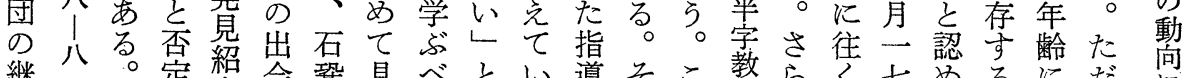

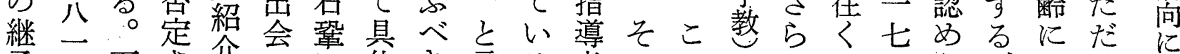

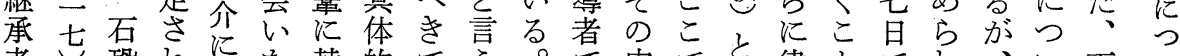

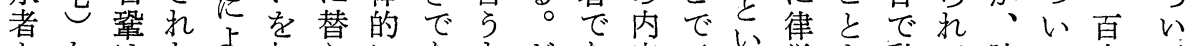

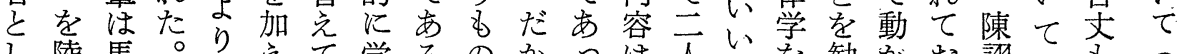

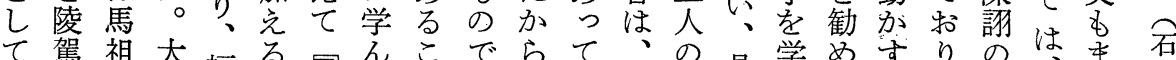

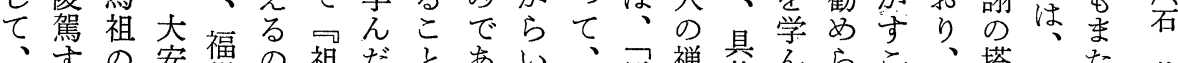

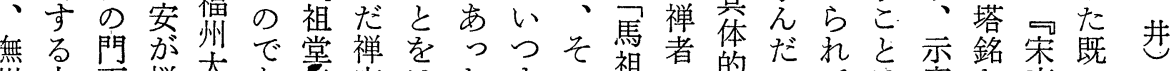

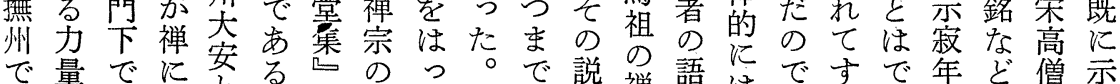
で量でに安る们ので説禅語はですで年ど僧示

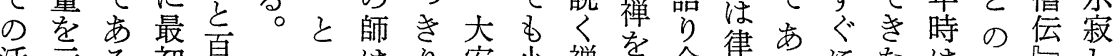

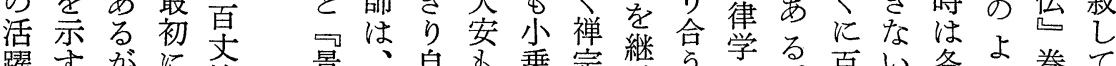

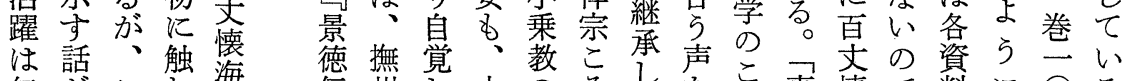

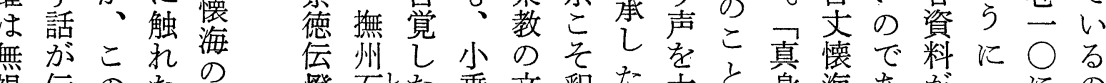

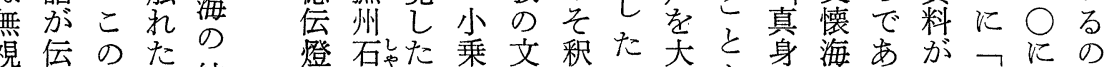

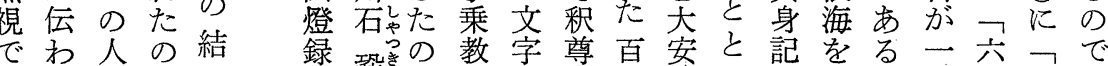

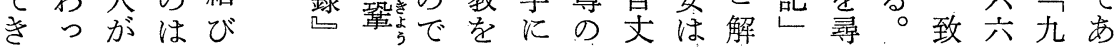

で、にっすは訓な義でな

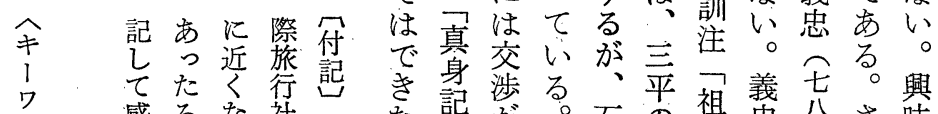
1. 喊万尔福第な記が。石の祖忠八さ味

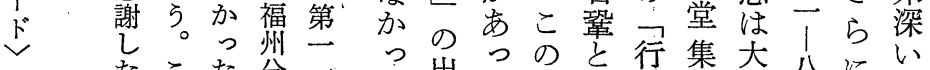

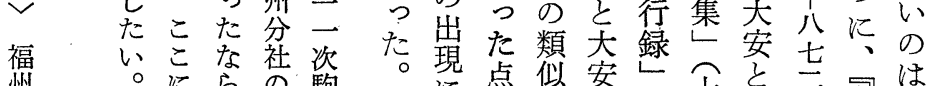

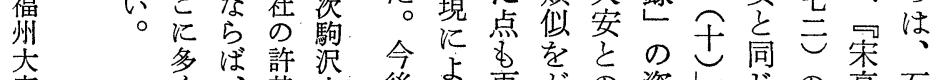

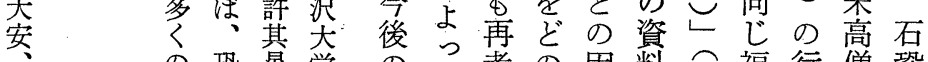

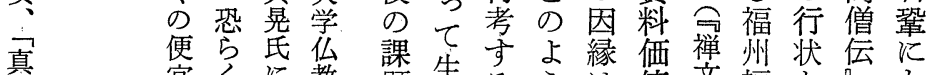
竐

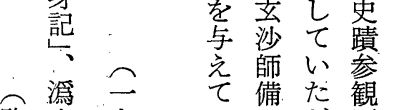

駒山九い出た観 沢旮怡塔卡注

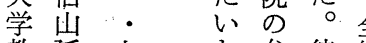
教延七店彼線 授寿・許観 の通

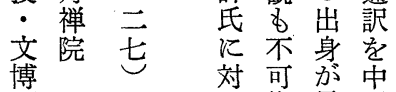
博

て 能昇国

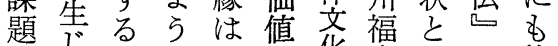
と必浓货唐のの牧 乙譇要考義認第県類 (4) 牛 た譇唯忠め牙の似のの 以閴あるのる四出が大話 題万か話。回身み安が は5、筆号芯伝伝 分。ま乞者、机をわ

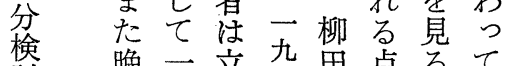
馀晚一立杂田点るて 分年般場厹聖主とい こ 一滛年山見: る こ 云伝異夏氐逃严こ 